\title{
Drugs or Brains
}

Citation for published version (APA):

Riedel, W. J. (2019). Drugs or Brains: Who obeys? Maastricht University. https://doi.org/10.26481/spe.20190215wr

Document status and date:

Published: 01/01/2019

DOI:

10.26481/spe.20190215wr

Document Version:

Publisher's PDF, also known as Version of record

\section{Please check the document version of this publication:}

- A submitted manuscript is the version of the article upon submission and before peer-review. There can be important differences between the submitted version and the official published version of record.

People interested in the research are advised to contact the author for the final version of the publication, or visit the DOI to the publisher's website.

- The final author version and the galley proof are versions of the publication after peer review.

- The final published version features the final layout of the paper including the volume, issue and page numbers.

Link to publication

\footnotetext{
General rights rights.

- You may freely distribute the URL identifying the publication in the public portal. please follow below link for the End User Agreement:

www.umlib.nl/taverne-license

Take down policy

If you believe that this document breaches copyright please contact us at:

repository@maastrichtuniversity.nl

providing details and we will investigate your claim.
}

Copyright and moral rights for the publications made accessible in the public portal are retained by the authors and/or other copyright owners and it is a condition of accessing publications that users recognise and abide by the legal requirements associated with these

- Users may download and print one copy of any publication from the public portal for the purpose of private study or research.

- You may not further distribute the material or use it for any profit-making activity or commercial gain

If the publication is distributed under the terms of Article $25 \mathrm{fa}$ of the Dutch Copyright Act, indicated by the "Taverne" license above, 
Prof.dr. Wim Riedel

Faculty of Psychology and Neuroscience

Drugs or Brains. Who obeys? 


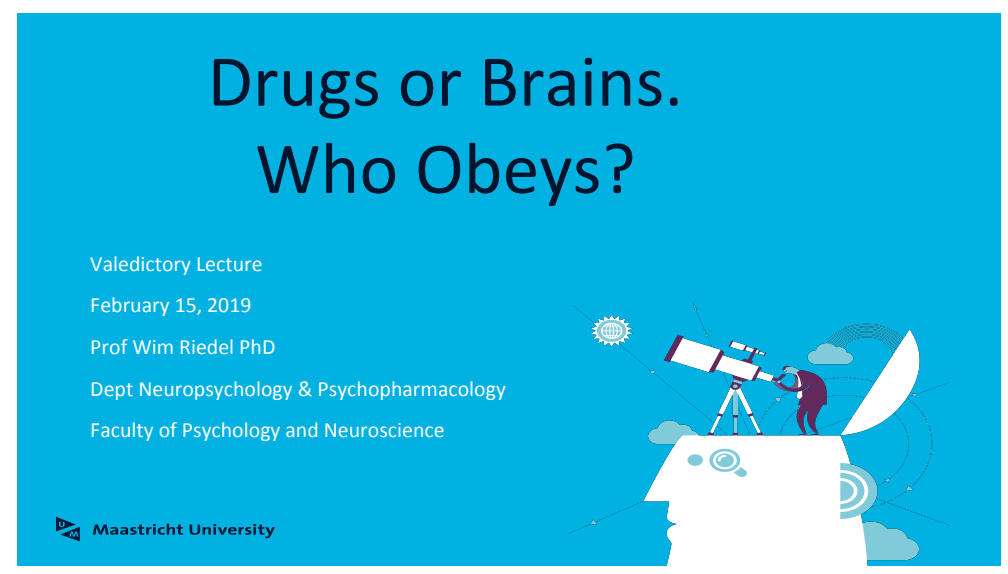

Respected Dean, members of the board of the Faculty of Psychology \& Neuroscience, distinguished colleagues, family, friends and all other listeners.

What a strange title, you must have thought when you first saw this. For me it is very logical though and I hope at the end of this talk you will think the same. So for everyone in the audience, understanding the title is my intended learning outcome for today. Someone asked me: "What is a farewell speech at a University? Do you have to keep it academic or is it mostly a victory lap?" My answer was that it may be somewhere in between: a very selective academic review of the area I worked in, understandable for a broad audience, looking back and looking forward, mixed with my memories and an attempt to entertain.

Let's kick off with that. These days it is common, if not required, at the start of a presentation to declare possible conflicts of interest. What we then very often see, at least at the meetings that I attend, is a long list of companies from whom the speaker has received payments in the recent past. Obviously, the longer such a list, the more impressive it is perceived to be. But I have almost nothing to declare. Yes I have worked in 2 big pharma companies and no doubt I am still influenced by that, but I think mainly in terms of that it has broadened my horizon and expanded my scientific knowledge, much more than when I would have stayed at University all the time.

Referring to my past work as a research scientist in big pharma companies, the joke is that I have been introduced to students as the Professor who came back from the dark side, if that hasn't just happened already I am doing so now.

You could also say I have flown out of that golden cage because I don't care so much about bling-bling. 


\section{Conflicts of interest (COI)}

- Yes I have worked in big Pharma: GSK and Roche

- But I came back from the dark side

- No I don't have shares (anymore)

- I play in a band (10c Trinkets) and will try to sell CD's

- These COI slides are always misused to boost one's ego ....

Maastricht University

But I could have completely different motives and this declaration is to make you aware of it.

\section{Content}

1. Before the beginning - a blast from the past

2. The beginning - Institute for Drugs, Safety \& Behavior

3. The background - Development of New Medicines

4. Top Down vs. Bottom-Up

5. The middle - depression, some cheering up ...

6. Placebo, the best fake-drug?

7. Towards the end-dementia

8. The end - new researchers, new treatments!

Maastricht University

What you can expect is the 8 paragraphs as outlined here.

The most salient aspects of my work will be highlighted, I will take you on a tour through some of my past and current experiences, prime interests and fixations.

1. My Interests before University

1. My interests before University

- The Dark side of the Moon . . . . . .

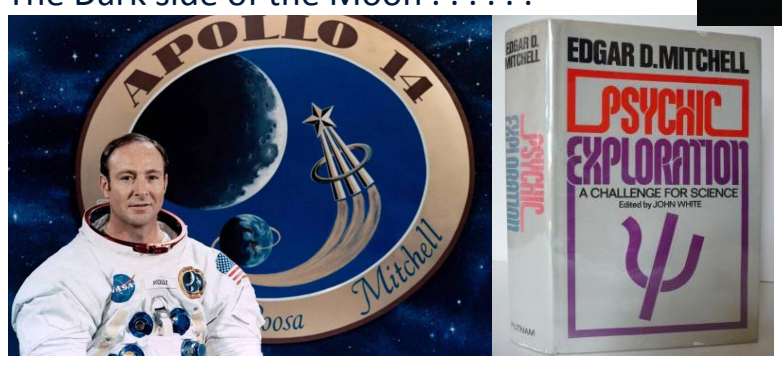

Maastricht University

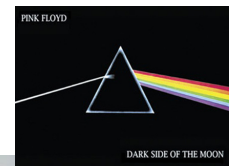


OK, let's have a blast from the past in an attempt to explain how I got here. When I was a teenager, like most in the seventies, I was fascinated by space travel, so each time there was a space mission, the family clustered at the radio or TV and listened to those sound bites like 'Houston, we have a problem'. In those days I became also fascinated by the music of Pink Floyd, so even before I had ever touched my hands on any psychoactive substance I was already of the opinion that this kind of music was mind-altering, changing consciousness, like others claim that drugs do, but much healthier. Lyrics on the famous Pink Floyd album dark side of the moon refer to several themes that occurred later in my scientific career, such as: 'Luna-tic', 'Brain damage' and 'There's someone in my head but it's not me'. And the book 'Psychic Exploration' binds this together, it was written by Ed Mitchell, astronaut on Apollo 14 , he was the sixth man on the moon. The concept 'dark side of the moon' first got public attention when Apollo 8 astronauts were orbiting the moon for the first time, so when they were at the dark side, behind the moon, or as it was called officially, at the far side of the moon, no radio-communication was possible. Ed Mitchell though, claimed he was telepathic and tried to seek telepathic contact with someone on earth when Apollo 14 was at the dark side of the moon. He claimed this as important existential evidence for paranormal phenomena and that is what Psychic Exploration is about. As a teenager I was very intrigued by the concept of paranormal communication and I wanted to understand this and develop these skills (perhaps to compensate for my poor social skills at the time). That was why I turned to studying Psychology. The program in Groningen, quickly cured me of my belief in my telepathic skills (it wouldn't make sense anymore now anyway, because we all have mobile phones; only at the dark side of the moon, telepathy would still be an asset).

\section{Institute for Drugs, Safety \& Behavior}

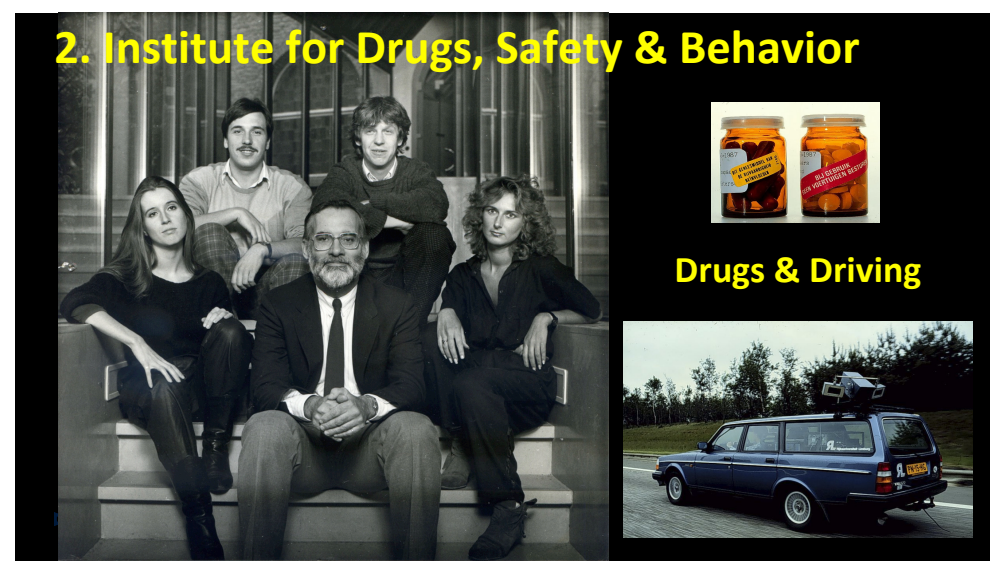


However, I landed on a different planet, the Institute for Drugs, Safety \& Behavior. This picture appeared on the front page of the Maastricht University newspaper the Observant in September 1986 and everybody referred to it as "Charlie's Angels". Jim O'Hanlon founded it, he transferred the research program 'Drugs \& Driving' from Groningen to Maastricht and the first claim of success, is for Jim O'Hanlon, but I'd also like to declare my share, is that this research program still exists today within the Faculty of Psychology \& Neuroscience - the claim of cusses is also for Jan Ramaekers who leads it now. And as you may be able to see, the Head of Instrumentation of this faculty, Huub Hamers, also started his career there. The focus of the drugs and driving program is to discover whether prescribing existing or new medicinal drugs pose a danger for activities in daily life such as driving a car in traffic. The easiest example is to think of alcohol. After too many drinks no one is capable of driving because brain functions, and therefore important cognitive and motoric capacities have become insufficient or maladaptive. The same principle can be applied to studying behavior under the influence of psychoactive substances, mostly reflected by the question: 'at which dose does influence become apparent and how does it relate to the chemical properties of the substance?' But as said the strength of the Drugs \& Driving program is that it is focused on the question if a certain substance (a medicinal drug, or an illicit drug, or perhaps even a nutrient) has safety related side effects in a very important daily life activity and if so, above what dose. Thinking back of this, my best memory is the speed and the dedication with which we started. The instrumental car had to be built-up with measurement devices and a computer. But first it had to be collected at the Volvo garage. It was and still is the only time in my life I picked up a brand new car at a garage, so at the time I had no script for the moment the garage manager asked me to sign it onto my name. I thought that can't be right, because my insurance won't cover this, it should be on the name of the University. So I called my boss Jim O'Hanlon and asked who was to sign this? It should have been the head of the university's facility services, but it was Holiday time, Friday afternoon and Jim told me, 'just put it on your name and bring it here', 'we urgently need to start building it up'. So I obeyed and I got the instant bonus: 2 bottles of wine from the Volvo garage! 


\section{Development of new Medicines}

The study of side effects was a good start so I went on for the real thing: investigating therapeutic effects of medicinal drugs and ultimately the question how do you develop new medicines. As you can see here the drug discovery and development pipeline is a rather long process with several stages and the ones with the red arrows are where I have been working in.

Limiting it to disorders of brain function, this is about finding new medicinal drugs and testing them under strictly controlled conditions according to the highest scientific standards. In this way empirical data are collected showing evidence that novel compounds work for neurological indications like dementia, parkinsons disease, multiple sclerosis, migraine and so forth. And likewise for psychiatric indications like depression, schizophrenia, autism, ADHD, and so forth. Basically, all brain diseases that can be targeted biologically.

Zooming out you can see that the so-called neuroscience drugs, medicines for neurological and psychiatric diseases, have comprised about $20 \%$ of all new medicines over the past 25 years. And to be more specific, we are talking about on average 7 new neurological and 4 psychiatric medicinal drugs per year over the past 25 years.

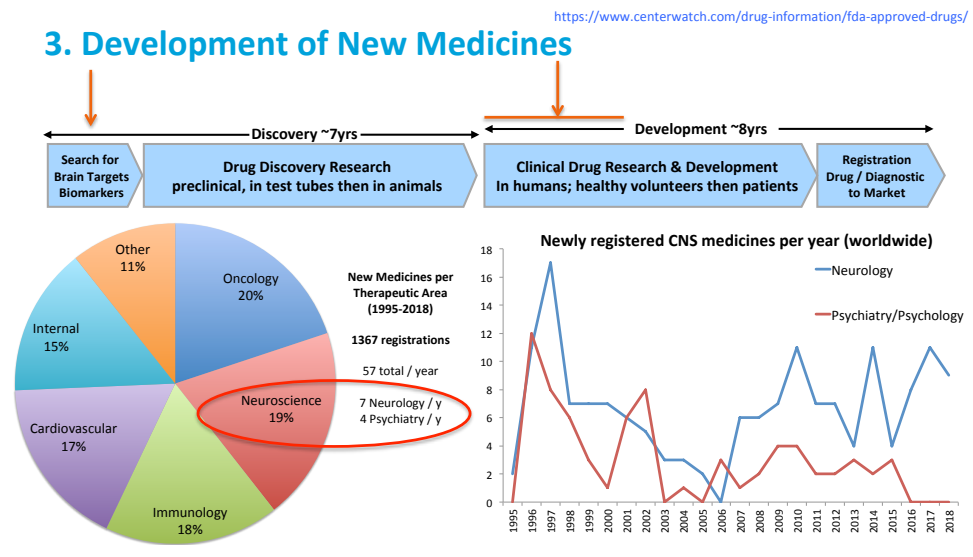

But when we look in more detail at these past 25 years we can see that there were still relatively many new psychiatry drugs in the 1990s and early 2000, but at present, the last 4 years, no new drugs have been registered in psychiatry. Only neurology drugs were registered recently. For example 2 new drugs were ocrelizumab for multiple sclerosis in 2017 and erenumab for migraine in 2018. Both are so-called biologicals 
rather than small molecule drugs, they are antibodies. These are really new in class medicines with a different mode of action than their precedents and much more efficacious as well. But also because these are a new class of medicines they were approved, but with the requirement that for several years safety data need to be systematically collected and evaluated.

4. The Anatomy of Bottom-up and Top-Down

4. The Anatomy of Bottom-Up and Top-Down

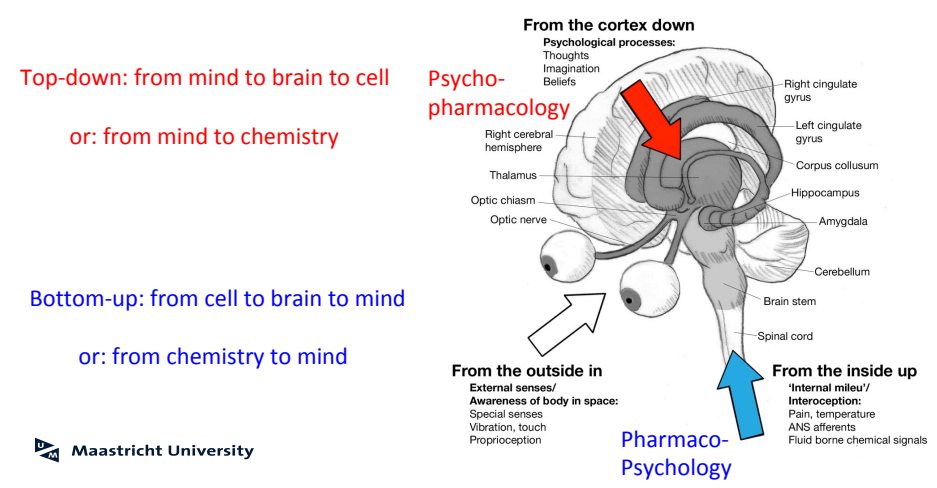

Now for something completely different. When we talk about the science of how drugs, substances influence human behavior, we always talk about psychopharmacology, but there are actually 2 different ways we can study this. The most dominant mode of thinking about this is that the properties of the substance such as the dose and the duration of action and also whether it is able to enter the brain predict its effects on experience, feeling the drug, and behavior. And these factors we call the Pharmacology of the drug. And when it concerns brain effects we call it Psychopharmacoloy. But actually this is wrong. We should call it Pharmacopsychology.

Because the important assumptions concern the causality. A drug is ingested absorbed, distributed via the bloodstream to the brain where it binds to certain neurotransmitter receptors, and from there neurophysiological processes are changed and psychological effects can be observed. Therefore the word Pharmaco Psychology. From Cause to Effect; Bottom Up, or from simple to complex. 
We need to realize though that the true meaning of Psychopharmacology is the science of how mind, or thoughts, or behavioural intentions affects the chemistry of the brain, so here the causality is opposite. Think about how we often in daily life use expressions such as "I felt the adrenaline running through my veins" to express some form of excitement. Of course you don't feel that - even though it may be true -, at best you can feel heart pumping and sweating, well, those would be the biomarkers. But we assume that the commands for these biomarkers come from above, from the brain. Therefore cause effect is Top Down, from complex thought to lower level physiological processes.

And how is this relevant for drugs. I like to quote a study (Rush et al, 2001) that focused on how drug naïve human volunteers experience or feel drug effects. Healthy volunteers received different doses of amphetamine, methylphenidate - known as Ritalin - and placebo. Amphetamine and methylphenidate are both stimulant drugs, if anything, they increase heart rate and breathing rate, they generally increase mobility and talking. These subjects were asked to rate if the drug that they had taken was a sedative/downer, a stimulant/upper, or placebo. The most striking result is that $75 \%$ of healthy volunteers rated d-amphetamine and methylphenidate as sedative/downer and $25 \%$ as stimulant/upper; none thought it was placebo. Placebo was identified as a "placebo/blank" (63\%) or "sedative/downer" (37\%); none thought it was a stimulant. Drug effects are most commonly misinterpreted in drug-naïve young men. There is an Age effect: experiencing drug effects is a Learning process. There is also a Gender Effect: Females are better at interpreting drug effects, probably because they are better at interpreting their own bodily signals? This experiment makes you wonder if the drug effect is determined by the drug (bottom-up) or by the brain: in terms of what the subject expects (top-down). So who obeys? And to make another leap: in early drug development, we work a lot with asking subjects what they feel, either by interview or by rating scales, so here is an area for improvement: they should be trained into drug connoisseurs first.

\section{Depression}

Strangely, there are no common references to neurotransmitters about depressed mood, such as I felt low on serotonin, or I felt too low or too high on glutamate. More 
common is to say, I feel the blues, I feel sad, or I feel gloomy, so purely behavioral descriptions. And when this goes on too long, we call it major depression. But scientists have searched for a biological basis of the concept of depression for very long. In this scheme you can see in the development over the years that we went from the monoamine theory of depression - that is indeed assuming low on adrenalin and low on serotonin is causing depressed mood - leading to the first antidepressant drugs in the 1960s to one that focused specifically on serotonin, leading to the SSRIs in the late 1980s where we actually still are now, in terms of registered drugs. But as you can see there are still 2 unresolved problems, which is the high number of refractory patients, many say $40 \%$ of patients is actually the maximum number that benefit from these drugs. And the next problem is the latency, or the time it takes before a therapeutic effect will manifest. The latest hypothesis is that of a glutamatergic mechanism, like we know is present in ketamine, is capable of delivering immediate antidepressant effects. Presently there is one candidate new antidepressant drug, esketamine, an intranasal formulation of a powerful anesthetic called ketamine, better known in party circles as "special K", very close to approval by the FDA.

This is after 50 years of failed biological hypotheses about major depression (for example antagonists of neurokinins, corticotropins, metabotropic-glutamate receptors all failed). The real problem is that we cannot measure depression, at least not its biological construct, we still have no biomarker of depression, so the serotonin hypothesis of depression is very questionable. And because we don't have a depression biomarker, Adam Cohen from the Centre for Human Drug Research in Leiden in his farewell speech last year said: "Personalised medicine in Depression is like Having a suit fitted by a blind tailor".

\section{Depression}
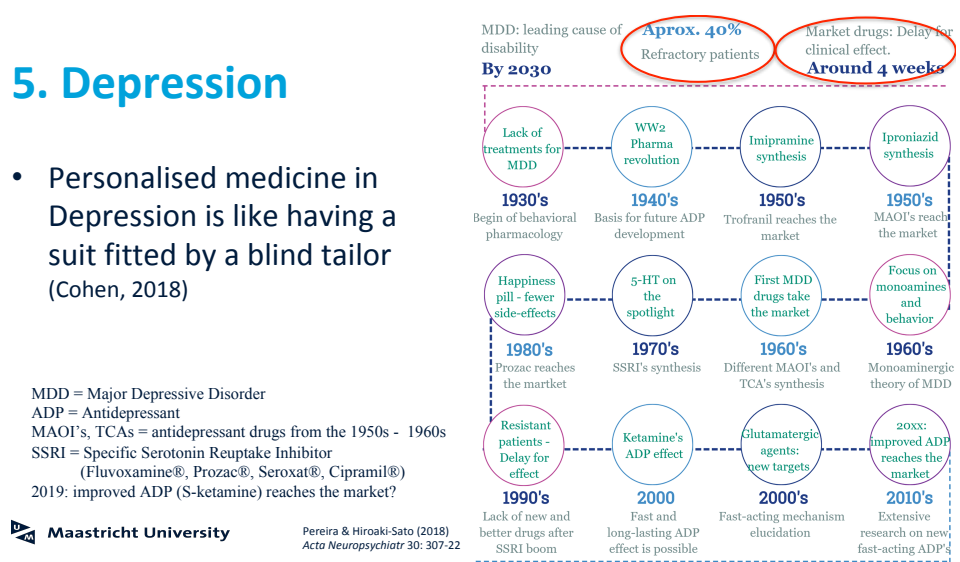
But having said that, manipulations of serotonin definitely have measurable effects, both in animal and human subjects. Mechanistic studies all show that SSRIs have immediate effects mediated by the brain, for example on pupil size, on cortisol, on facial emotion recognition and memory. Yet the patients do not immediately feel better on it. Initially they often feel severe side effects, like nausea and gastric discomfort.

So what does an SSRI do on behavior? Most salient effect: increasing social dominance. And it has been demonstrated to do so already after the first dose. Simon Young writes: "Increasing serotonin decreases quarrelsome behaviours and enhances agreeable behaviours in humans. Antidepressants act in part by effects on social behaviour, which leads to a gradual improvement in mood. Positive social responses of interaction partners triggers a cycle of positive social behavior, and this iterative process leads to clinically significant improvement in mood." (Young et al, 2014). A combination of aggressive and affiliative behaviors is important for achieving social dominance. Facial emotion expression of social partners plays a key role in achieving dominance status. SSRIs enhance reward sensitivity to the facial emotions of social partners (Tse et al., 2014) and that is the key mechanism.

For example, when you have a colony of monkeys there is a social hierarchy, the most dominant, or the alfa monkey is number one and has the least stress. Not the lowest in rank, but typically the number 2 and the number 3's are the most stressed. So if you give number 3 an SSRI it climbs in rank to become number 2 .

So one obvious paradox is: if all are taking SSRIs nobody benefits. And also: in humans these effects may be more covert and more subtle.

Because this may all be very abstract, let's consider a case from real life. Well, from a real newspaper, the Volkskrant Saturday magazine with the weekly sent-in letter by a reader, with a problem and then the question what would you do? Along with the selected responses a week later. When I read this one, I thought it may actually illustrate an antidepressant effect in real life, because what the message reflects in my opinion is the shift in social rank, that is positively evaluated by the patient, but is not always appreciated by others in the life of the patient. As such, I thought this was a perfect example of the consequence in daily life of the effect of an SSRI, at least if it was indeed an SSRI. Because the letter didn't say what the drug and the dose was. And I have to confess to you that I very often thought that these so-called reader letters are constructed. So I thought I am just going to ask the editors whether they 
know the name of the drug and the dose or if they can still ask. In this case, the threshold is low because my stepsister works at the editorial board of this newspaper, so I asked her the question. It's a big newspaper of course and this was not her department, so she forwarded the question for me and to both our surprise we got a relatively quick and very detailed answer and the permission to share it in this presentation.

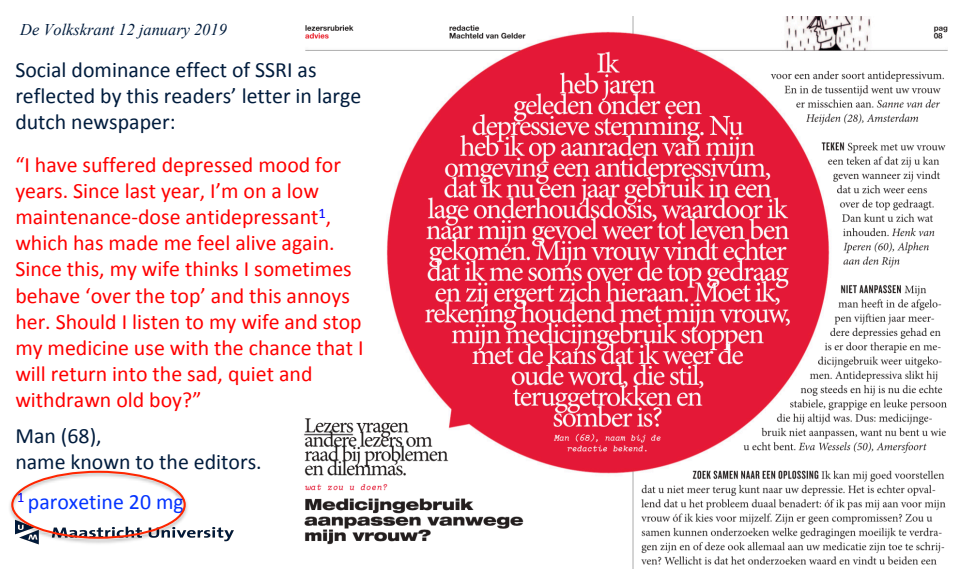

To put it short, the answer was paroxetine $20 \mathrm{mg}$ once daily. It is indeed an SSRI, whether this can be considered a low dose is a matter of debate, but at least it fitted perfectly well with behavioral changes that I thought you can expect after an SSRI. The patient also wrote back in response to my question, that by now, he is more stabilized on the medication and his wife has adapted to his new and improved persona and actually appreciates it more. Finally, this also made clear to me that these letters are real, they are not fake!

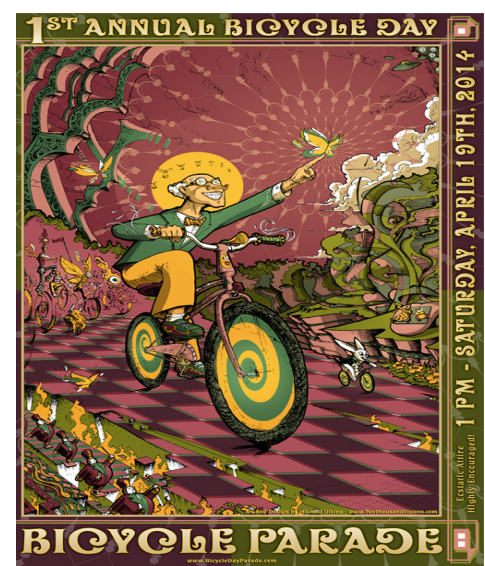

\section{Psychedelics}

- Albert Hoffmann (Sandoz) cycling through the streets of Basel on an accidental dose of LSD .... (19 april 1943)

- Microdoses of psychedelic drugs are now under investigation as novel antidepressant drugs 
Now let's turn to the next era of antidepressants perhaps: psychedelics. Yes indeed, this is about LSD, psilocybin and related substances. In the last table you saw that attention in antidepressant drug development had moved from serotonergic drugs to glutamatergic drugs like esketamine. In psychedelics, both serotonergic and glutamatergic mechanisms are active and like ketamine they have an immediate effect on mood. They were banned after 1967 mainly because of their so-called hallucinogenic or pro-psychotic side effects. But during the last 10 years, scientific interest in the mechanisms of action in these drugs has revived. Recent trials with psychedelics in major depression, mainly with psilocybin, show initial evidence of safety and efficacy, so this is very promising, only the regulatory and legal hurdles to licensing psychedelics as medicines remain high.

It might be possible to tailor these substances in such a way that the potentially therapeutic mechanisms that induce the positive effects on mood are maintained and the psychotic side effects are engineered out, firstly by looking at lower dose levels. The near future will have to tell us whether this is effective.

When I lived in Basel, I cycled a lot, but I never knew about this annual cycling day to celebrate the discovery of LSD.

But it is a typical example of the paraphernalia that can be associated with certain drug effects. As I said in the beginning, music can have this effect very strongly too and many popsongs are associated with this, but there is one that cannot be unheard when considering psychedelic drug effects. So here is where we get high with a little help from my friends. One moment for tuning and some mind-altering music will be administered to you.

-- singing --

For those who don't know it: This was White Rabbit by Jefferson Airplane The author, Grace Slick, singer of Jefferson Airplane, was strongly influenced by fantasy stories that were read to her as a child, such as Alice in Wonderland. She said White Rabbit stands for following your curiosity and for not always obeying others. And I think that is an essential role example for scientists. One other line from the song refers to placebo: the ones that mother gives you, don't do anything at all. In addition, she actually gives some sound methodological advice for drug researchers: one pill makes you larger and one pill makes you small. That could be taken as: you 
have an investigational drug and an active comparator or reference drug, against which you would like to make the new drug look better or bigger and another reference - placebo - that doesn't do anything at all. Or it could also mean 2 doses of an investigational drug versus placebo.

\section{Placebo}

One other way to get to placebo, but also to get cycling back in this story is the clinical trial on the effects of Erythropoietin, or EPO, on cycling by the Centre for Human Drug Research in Leiden. What I like about this study in particular is that where everybody, and I have to admit including me, believes that it is absolutely beyond any doubt that taking EPO gives cyclists an unfair advantage, there was actually no empirical evidence from any controlled scientific experiment or trial, with adequate placebo and blinding.

Highly competitive amateur cyclists received EPO or placebo and performed several tests on physiological functions and ergometers and a real over the road cycling event, up the Mont Ventoux. And what they found even surprised me, they wrote that although the well-known effects of EPO on hematological and physiological parameters were indeed observed, that is: more red blood cells and more oxygen uptake after EPO relative to placebo, this did not translate to better cycling performance either in the laboratory or on the road.

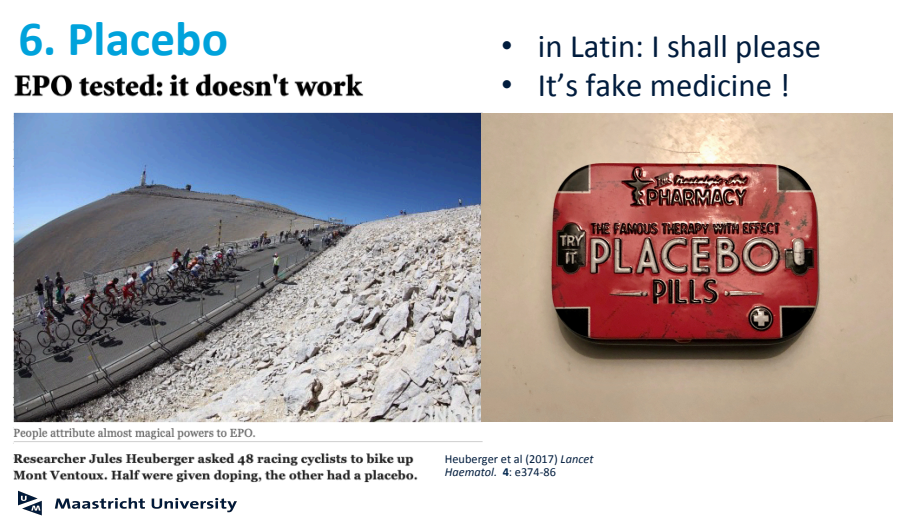


I take this example because even though it is not strictly neuroscience, it is the most stunning example of a placebo-effect and the powerful influence of expectation about drug effects in the individual taking them. It is typical that this scientific fact is completely discarded by the professional cycling world. They just don't believe the data. The only thing I could say is that, it would need a replication, and I herewith volunteer for participating in it. It is also interesting that this is a typical example of a drug effect that gets lost in translation. What I mean with that is that the mechanistic effect can be demonstrated in the laboratory, the increase of red blod cells and hematocrit values as well as the increase in oxygen uptake by EPO, but it doesn't translate to better performance.

\section{Dementia; Drugs and/or lifestyle}

OK, that was the uphill battle, now let's look at the downhill struggle. This graph is a very typical simplified representation of the gradual decline of cognitive functioning over the years in patients with mild to moderate alzheimers disease and how it is influenced by the only category of registered medicinal treatment to date. As you can see the blip in the graph may give 1-2 years extra but it doesn't stop the process. That's why this drug is called symptomatic. And to introduce another case example: during the nineties I worked in the memory clinic under the supervision of Jelle Jolles and Frans Verhey, working on several clinical trials investigating potential new Alzheimer medicines. Looking back now, these were all symptomatics and we never saw any effects. Yet, when the moment to use one was there, in 2008, it was my mother, then aged 89, who was in the process of typical Alzheimers Disease and I couldn't resist initiating that we asked her doctor to prescribe an anticholinesterase inhibitor, because I had the feeling she was the perfect patient. No comorbidities and still motivated to perform cognitive activities like reading the newspaper out loud. To make a long story short we saw that blip, perhaps even a little bit bigger than as shown here in the graph. So it gave approximately 2 years extra in the period where somewhat normal communication was still possible. So it worked much better than I expected. It didn't cure my mother - she died last year at age 99 - but at least I saw some of my knowledge and years long research justified. 
But what we really need is a disease modifier, a drug that prevents or stops the underlying disease that causes Alzheimers Dementia. In the next slide I will show there are still many candidate drugs for that, but we still haven't found what we are looking for.
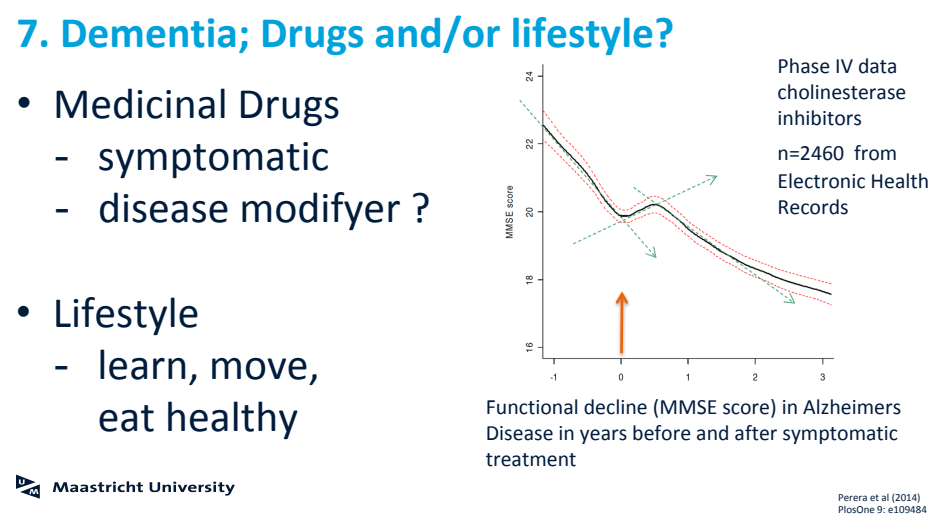

For that reason it is just as important to work on the so-called life style factors that may prevent the onset or decelerate the process of alzheimers disease. In short: Learn, Move, Eat healthy. Credits to the colleagues of the memory clinic who set up the project: "We are the medicine ourselves". I totally believe in it, I definitely am very good at the first two, and struggling with the third one. Yet, my memory isn't as good as when I was 20.

What you see here are many dots and each represents one drug that could have a therapeutic effect in Alzheimers Disease, but these effects have yet to be clinically demonstrated. On the left symptomatics, on top the biological disease modifiers, on the right the small molecule disease modifiers. Red dots are targeted on amyloid plaques, blue dots are targeted at tau. But although there are many candidate drugs, no new drug has really been registered since the nineties and not a single disease modifier has got to the finish line yet. Optimism about the possibility to cure Alzheimers Disease by removing or preventing amyloid plaques has diminished to near zero after more than 25 years of drug development. But I thought I absolutely don't want to leave you with no hope, so I very selectively singled out one very surprising new drug candidate, COR388 it has just got into Phase 1. 


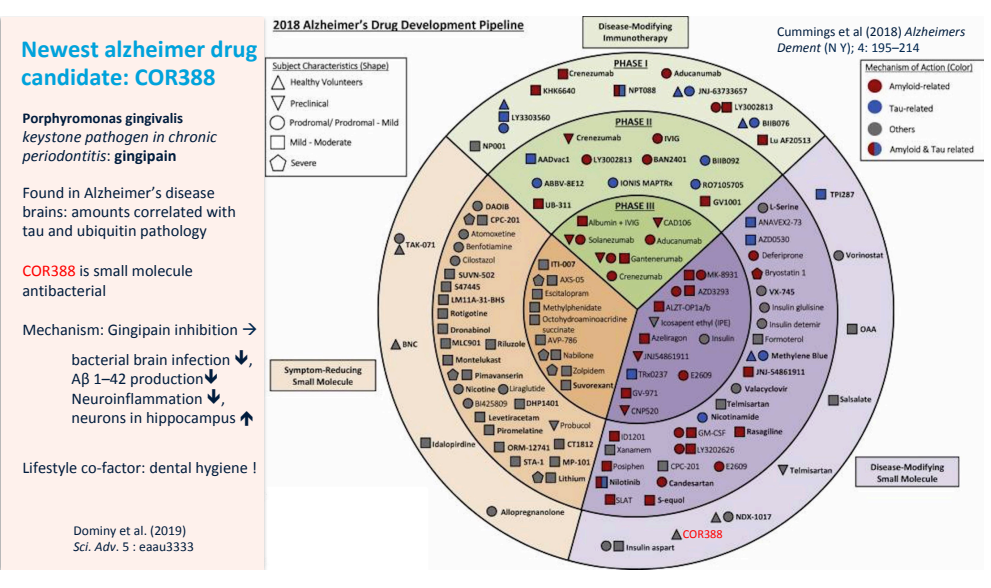

This is basically an antibacterial that is aimed at so-called gingipains, and these are bacteria known for causing periodontitis, they have been found in the brains of Alzheimer patients and are associated with formation of amyloid plaques and tau. An association of Alzheimers disease with periodontitis has also been demonstrated. Therefore another important lifestyle factor in the prevention of Alzheimers Disease may have been identified: dental hygiene. So maybe the lifestyle factors can be extended to: "Learn, Move, Eat Healthy and Always brush your teeth". But it is for the next generation of drug developers to bring this forward, we shall see.

8. Drug Development and Neurohealth

\section{Drug Development and Neurohealth}

- 2004: start FPN research master

- cognitive \& clinical neuroscience

- track 'psychopharmacology'? $\mathbf{x}$

- 2013: FPN Limburg agenda

- 'drug discovery \& development'

- 2014: group of staff from FPN and FHML formed

- 'drug development \& neurohealth'

- 2015: approved by faculty \& university board $\boldsymbol{V}$

- 2016: start first group of 14 students

- 2018: graduation first group of students

Maastricht University

And speaking of the next generation of drug developers, what I worked on in the past 5 years was setting up the research master drug development and neurohealth or DN. Here you see the landmarks that summarize its conception. 
Already during the start of the research master cognitive $\&$ clinical neuroscience, we talked about a track 'psychopharmacology' but at that time the idea wasn't mature enough.

I found documents from 2013 on where a track 'drug discovery \& development' was mentioned and let's say from there on DN was built.

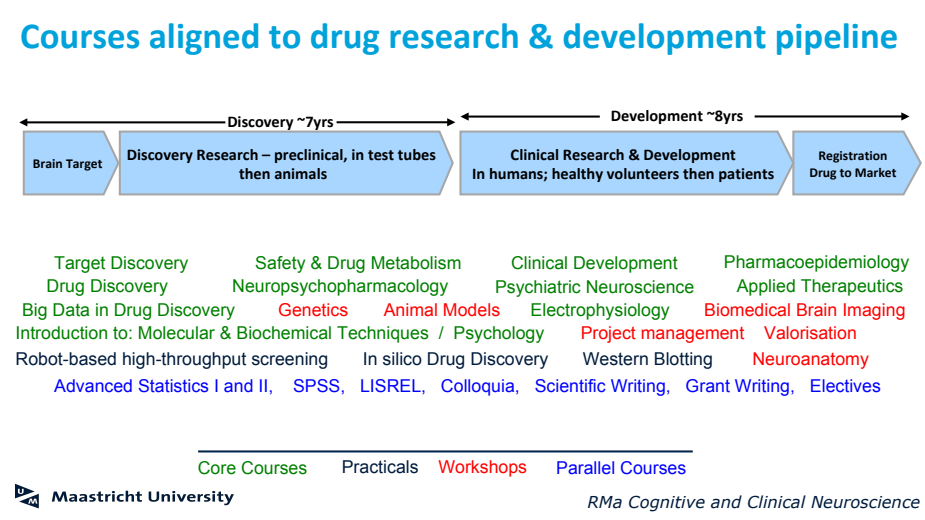

DN is built around the so-called drug discovery and development pipeline, as a perspective to learn the underlying science and view it in that light. All the core courses are at some point related to a stage in the drug discovery and development pipeline.

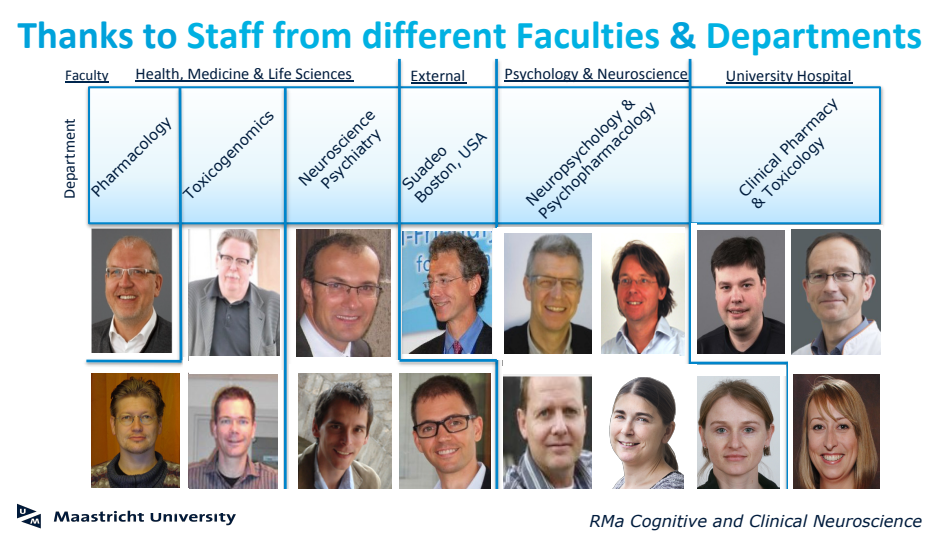

I thankfully use this staff slide that I also used in the so-called student recruitment pitches to illustrate the multidisciplinary character of the program. It is taught by different groups form 2 faculties and again from left to right it can be projected onto the early and late stages in drug discovery and development. And Thanks means here 
I start thanking everybody. Thanks to all colleagues who have contributed to the genesis and the actual carrying out of drug development and neurohealth.

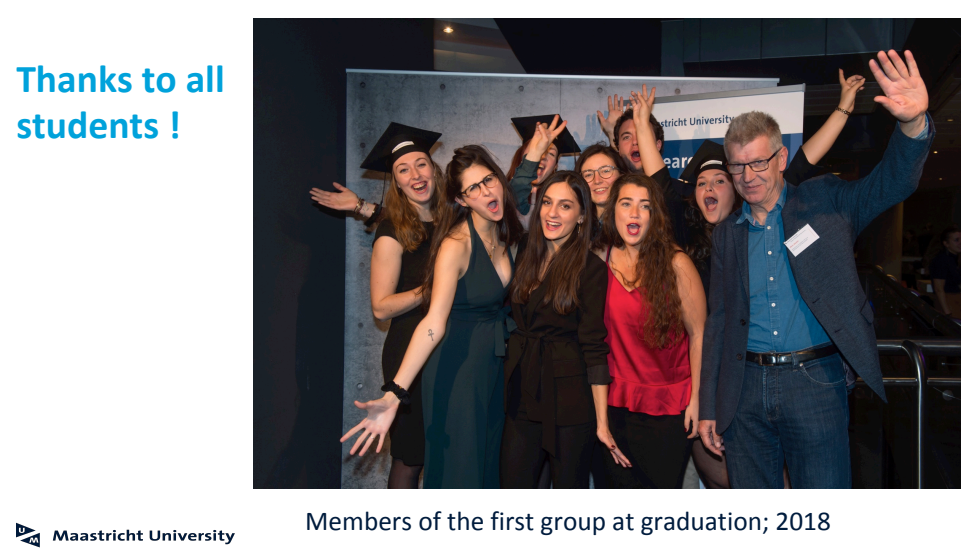

Thanks also to the students, or should I say they should thank me? In any case I really enjoyed teaching the first 2 groups of DN students but I think the picture tells it all.

\section{Thanks to all colleagues in NP and PP !}

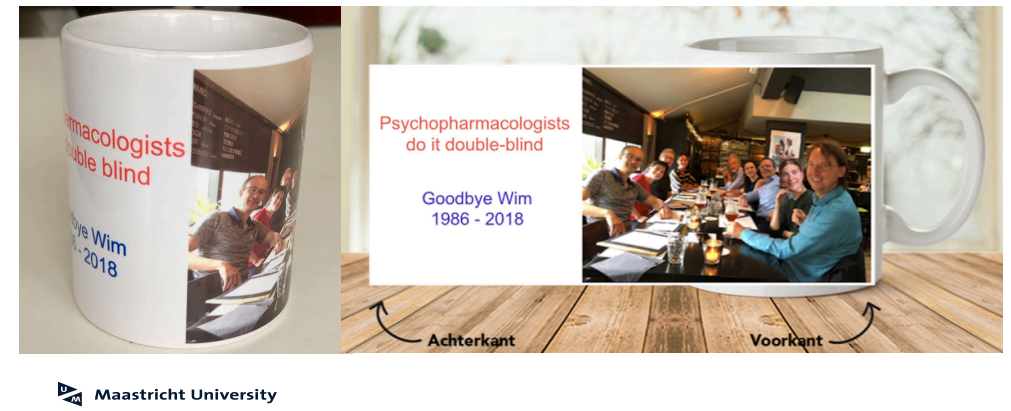

I also want to thank all my colleagues in Neuropsychopharmacology and

Psychopharmacology, especially those in Psychopharmacology and more specifically Anke Sambeth, Arjan Blokland, Eef Theunissen, Jan Ramaekers, Jos Prickaerts and Kim Kuypers. Because they treated me, amongst many things, on a railway cycling trip in the mountains in Belgium. I also want to thank Rudy Schreiber that he was willing to leave Boston for Maastricht and take over my role, so that I am reassured that DN is in good hands. What you see here by the way is valorization, or value creation, of colleauguial appreciation, there are only a few of these mugs and 
probably their value has gone up now. But feel free to use my famous one-liner: 'Psychopharmacologists do it double blind'.

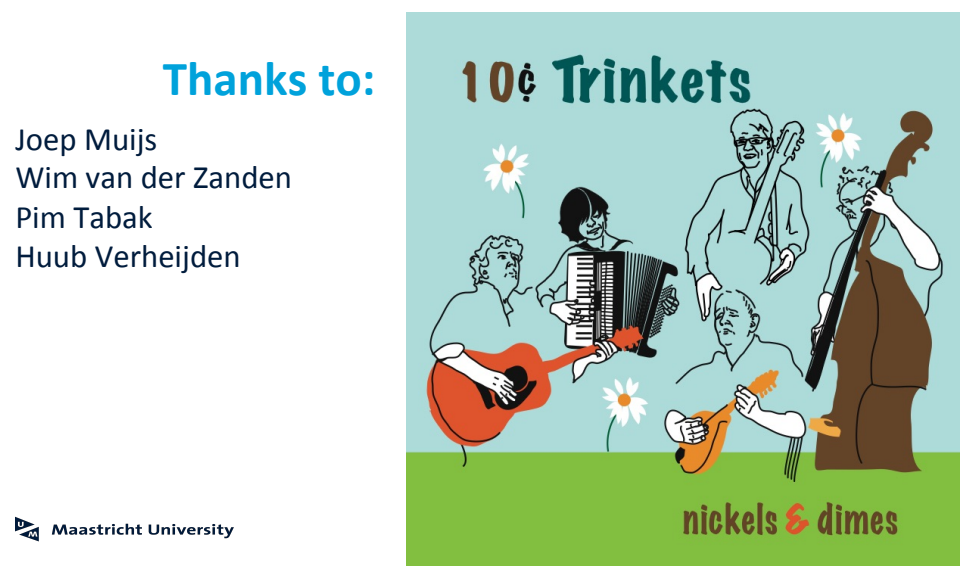

And now for the commercial break: Thanks to my friends from 10 cent Trinkets, Joep Muys, Wim van der Zanden, Pim Tabak and Huub Verheijden: drumming with you guys has definitely boosted my impact factor.

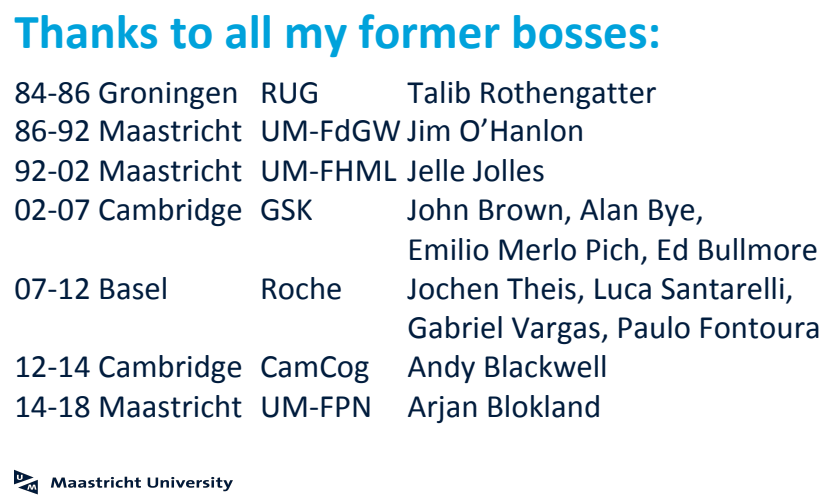

Who obeys all the bosses? Well I did, most of the time! I think it is typically me to put this in a table, put some numbers with it and run a big data analysis on it. And what do we see: they were all male. Well, that's coincidence. I nevertheless learned a lot from all of them. I will not mention them all but there are three here: Jelle Jolles, you survived me the longest with 10 years. Jochen Theis, the peculiar aspect of our working relation is to put it bluntly that I hired you in GSK and you hired me in Roche. Arjan Blokland, you have the honour to be my last boss. ... What you can see is that bosses are much more faithfull in academia. In industry I had a different boss 
nearly each year. Of course these are the direct reporting line bosses, there are also some on a higher-up level. And guess what?

They are the female bosses. Professor Anita Jansen the dean of faculty of Psychology and Neuroscience and Dr. Carolien Martijn the director of this faculty. Thank you very much for your support.

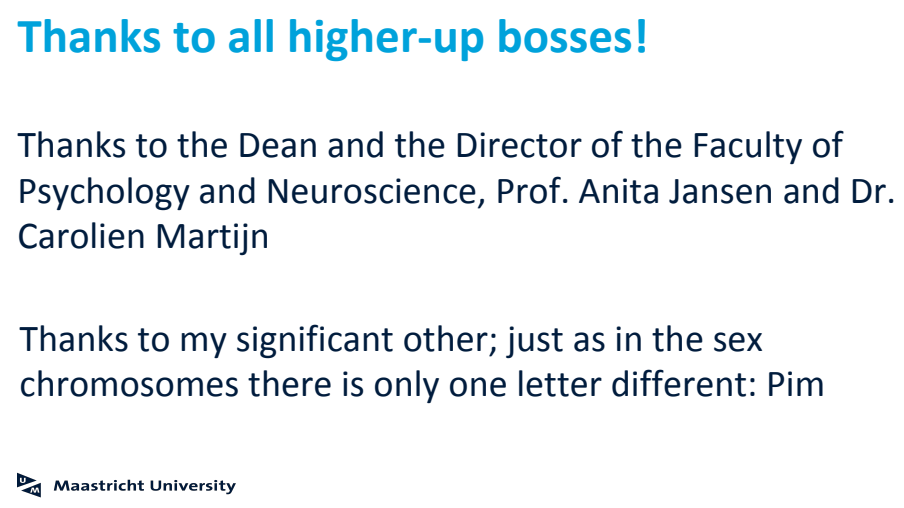

Finally, Pim Tabak, my dearest, my fairest: you were the real reason that I came back from the dark side to Maastricht.

And so I have said. Ik heb gezegd. 


\section{References}

Cohen, A. (2018). Weg met het Geneesmiddel. Afscheidsrede Leiden University.

Cummings, J., Lee, G., Ritter, A., \& Zhong, K. (2018). Alzheimer's disease drug development pipeline: 2018. Alzheimers Dement (N Y), 4, 195-214.

Dominy, S. S., Lynch, C., Ermini, F., Benedyk, M., Marczyk, A., Konradi, A., et al. (2019). Porphyromonas gingivalis in Alzheimer's disease brains: Evidence for disease causation and treatment with smallmolecule inhibitors. Sci $A d v, 5(1)$, eaau3333.

FDA Approved Drugs (2019) https://www.centerwatch.com/drug-information/fda-approved-drugs/

Heal, D. J., Henningfield, J., Frenguelli, B. G., Nutt, D. J., \& Smith, S. L. (2018). Psychedelics - Re-opening the doors of perception. Neuropharmacology, 142, 1-6.

Heuberger, J., Rotmans, J. I., Gal, P., Stuurman, F. E., van 't Westende, J., Post, T. E., et al. (2017). Effects of erythropoietin on cycling performance of well trained cyclists: a double-blind, randomised, placebocontrolled trial. Lancet Haematol, 4(8), e374-e386.

Mitchell, E. D. (1974). Psychic Exploration: A Challenge for Science. New York: Perigee Trade.

Pereira, V. S., \& Hiroaki-Sato, V. A. (2018). A brief history of antidepressant drug development: from tricyclics to beyond ketamine. Acta Neuropsychiatr, 30(6), 307-322.

Perera, G., Khondoker, M., Broadbent, M., Breen, G., \& Stewart, R. (2014). Factors associated with response to acetylcholinesterase inhibition in dementia: a cohort study from a secondary mental health care case register in london. PLoS One, 9(11), e109484.

Rucker, J. J. H., Iliff, J., \& Nutt, D. J. (2018). Psychiatry \& the psychedelic drugs. Past, present \& future. Neuropharmacology, 142, 200-218.

Rush, C. R., Essman, W. D., Simpson, C. A., \& Baker, R. W. (2001). Reinforcing and subject-rated effects of methylphenidate and d-amphetamine in non-drug-abusing humans. J Clin Psychopharmacol, 21(3), 273-286.

Tse, W. S., Chow, H., Wing, Y. K., \& Bond, A. J. (2014). Using a partner's facial emotion to elucidate social dominance motivation induced by an SSRI. Eur Neuropsychopharmacol, 24(10), 1641-1649.

Young, S. N., Moskowitz, D. S., \& aan het Rot, M. (2014). Possible role of more positive social behaviour in the clinical effect of antidepressant drugs. J Psychiatry Neurosci, 39(1), 60-65. 